\title{
Erratum to: 22q11.2 duplication syndrome: elevated rate of autism spectrum disorder and need for medical screening
}

Tara L. Wenger ${ }^{1,2^{*}}$, Judith S. Miller ${ }^{2 \dagger}$, Lauren M. DePolo ${ }^{2}$, Ashley B. de Marchena ${ }^{2}$, Caitlin C. Clements ${ }^{2,3}$, Beverly S. Emanuel ${ }^{4,5}$, Elaine H. Zackai ${ }^{4,5,6}$, Donna M. McDonald-McGinn ${ }^{4,5}$ and Robert T. Schultz ${ }^{2,6}$

\section{Erratum}

After publication of the research article [1], the authors noticed a minor error in panel $\mathbf{d}$ of Fig. 3. The authors would like to draw the reader's attention towards the corrected Fig. 3 below. The corrected panel $\mathbf{d}$ reflects a very minor change which does not change the overall conclusion of the study.

Figure 3: This figure shows the corrected Fig. 3 of the original article.

\footnotetext{
Author details

'Department of Pediatrics, Seattle Children's Hospital, M/S OB.9.5204800 Sand Point Way NE, Seattle, WA, USA. ${ }^{2}$ Center for Autism Research, Children's Hospital of Philadelphia, 3535 Market Street, Philadelphia, PA 19104, USA. ${ }^{3}$ Department of Psychology, University of Pennsylvania, 3720 Walnut Street, Philadelphia, PA 19104, USA. ${ }^{4}$ Division of Human Genetics and Molecular Biology, Children's Hospital of Philadelphia, 3401 Civic Center Boulevard, Philadelphia, PA 19104, USA. ${ }^{5}$ 22q and You Center, Children's Hospital of Philadelphia, 3401 Civic Center Boulevard, Philadelphia, PA 19104, USA. ${ }^{6}$ Department of Pediatrics, University of Pennsylvania, 3401 Civic Center Boulevard, Philadelphia, PA 19104, USA.
}

Received: 7 July 2016 Accepted: 7 July 2016

Published online: 13 July 2016

\section{References}

1. Wenger TL, Miller JS, DePolo LM, de Marchena AB, Clements CC, Emanuel BS, et al. 22q11.2 duplication syndrome: elevated rate of autism spectrum disorder and need for medical screening. Mol Autism. 2016;7:27.

\footnotetext{
* Correspondence: Tara.Wenger@seattlechildrens.org

${ }^{\dagger}$ Equal contributors

'Department of Pediatrics, Seattle Children's Hospital, M/S OB.9.5204800

Sand Point Way NE, Seattle, WA, USA

${ }^{2}$ Center for Autism Research, Children's Hospital of Philadelphia, 3535 Market

Street, Philadelphia, PA 19104, USA

Full list of author information is available at the end of the article

Submit your next manuscript to BioMed Central and we will help you at every step:

- We accept pre-submission inquiries

- Our selector tool helps you to find the most relevant journal

- We provide round the clock customer support

- Convenient online submission

- Thorough peer review

- Inclusion in PubMed and all major indexing services

- Maximum visibility for your research

Submit your manuscript at www.biomedcentral.com/submit 


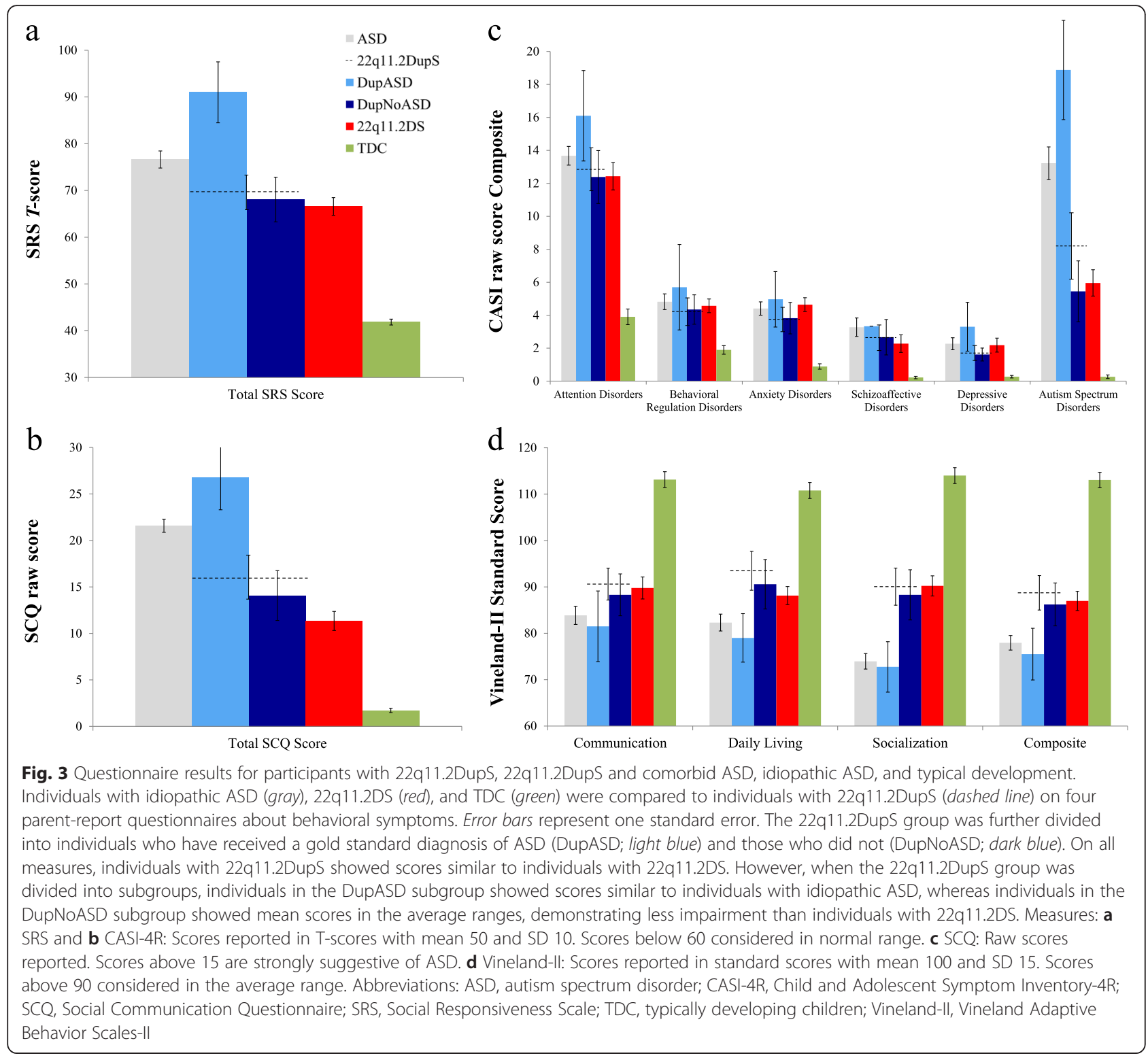

